\title{
АДМИНИСТРАТИВНАЯ ОТВЕТСТВЕННОСТЬ ЗА ПРАВОНАРУШЕНИЯ В СФЕРЕ ОХРАНЫ ОБЪЕКТОВ КУЛЬТУРНОГО НАСЛЕДИЯ В РОССИЙСКОЙ ФЕДЕРАЦИИ
}

$\mathrm{O}$ тношения в области охраны объектов культурного наследия в Российской Федерации регулируются Федеральным законом от 25 июня 2002 г. № 73-Ф3 «Об объектах культурного наследия (памятниках истории и культуры) народов Российской Федерации» (далее также - Федеральный закон № 73), а также принимаемыми в соответствии с ним другими федеральными законами, законами субъектов РФ и иными нормативными правовыми актами.

Согласно п. 1 ст. 33 Федерального закона № 73 объекты культурного наследия подлежат государственной охране в целях предотвращения их повреждения, разрушения или уничтожения, изменения облика и интерьера, нарушения установленного порядка их использования, перемещения и предотвращения других действий, могущих причинить вред объектам культурного наследия, а также в целях их защиты от неблагоприятного воздействия окружающей среды и от иных негативных воздействий. Государственная охрана памятников истории и культуры в Российской Федерации включает в себя установление ответственности за противоправные действия (бездействие) в отношении объектов культурного наследия, их территорий и зон охраны. Статьей 61 Федерального закона № 73 предусматривается уголовная, административная и иная юридическая ответственность должностных, физических и юридических лиц. Особое место в системе юридической ответственности занимает институт административной ответственности.

В соответствии с Конституцией России административное и административно-процессуальное законодательство находится в совместном ведении Российской Федерации и ее субъектов. Кодексом Российской Федерации об административных правонарушениях (далее - КоАП РФ) установлено, что законодательство об административных правонарушениях состоит из КоАП РФ и принимаемых в соответствии с ним законов субъектов Российской Федерации об административных правонарушениях. К ведению Российской Федерации относится установление административной ответственности по вопросам, имеющим федеральное значение, в том числе административной ответственности за нарушение правил и норм, предусмотренных федеральными законами и иными нормативными правовыми актами Российской Федерации. Субъекты РФ законами об административных правонарушениях устанавливают административную ответственность за нарушение законов и иных нормативных правовых актов субъектов РФ, нормативных правовых актов органов местного самоуправления.

В соответствии с задачами и принципами законодательства об административных правонарушениях в КоАП РФ установлена административная ответственность за нарушение норм, предусмотренных федеральными нормативными правовыми актами, регулирующими отношения в области охраны объектов культурного наследия.

K началу второго десятилетия XXI века правоприменительная практика показала слабую эффективность охранительных норм КоАП РФ, особенно в указанной сфере. Возникла необходимость в уточнении отдельных составов административных правонарушений и пересмотре санкций за их совершение. ${ }^{1}$ Кроме того, стало очевидным, что административная ответственность за совершение противоправных деяний в отношении объектов культурного наследия регионального и местного (муниципального) значения, а также их территорий и зон охраны также должна быть установлена КоАП РФ. ${ }^{2}$

Эту и другие проблемы предполагалось решить путем принятия проекта федерального закона № 163864-5 «О внесении изменений в Федеральный за-

\footnotetext{
1 См.: Панфилов А.Н. Проблемы применения мер административной ответственности за отдельные правонарушения в сфере охраны объектов культурного наследия в Российской Федерации // Государство и право. 2012. № 8. С. 26 - 34. Сумачев А.В. К вопросу о понятии культурных ценностей и совершенствовании административно-правового режима их охраны // Право и политика. 2012. № 12. С. 2074 - 2079.

2 См.: Панфилов А.Н. Охранительные нормы административно-деликтного законодательства субъектов Российской Федерации в сфере охраны объектов культурного наследия // Право и политика. 2013. № 6. С. $784-797$.
} 
кон «Об объектах культурного наследия (памятниках истории и культуры) народов Российской Федерации» и в отдельные законодательные акты Российской Федерации» (принят Государственной Думой Федерального Собрания РФ в первом чтении 17 марта 2010 г.) $)^{3}$ В статье 6 законопроекта формулировалась новая редакция статьи 7.13 КоАП РФ, предусматривающей в части первой административную ответственность за невыполнение установленных в соответствии с законодательством Российской Федерации требований к сохранению объекта культурного наследия независимо от его историко-культурного значения. На решение проблемы обеспечения охраны археологического наследия нацелен Федеральный закон от 23 июля 2013 г. № 245-Ф3 «О внесении изменений в отдельные законодательные акты Российской Федерации в части пресечения незаконной деятельности в области археологии» (далее также - Федеральный закон № 245). Однако точку в этом вопросе поставил Федеральный закон от 7 мая 2013 г. № 96-Ф3 «О внесении изменений в Кодекс Российской Федерации об административных правонарушениях» (далее также - Федеральный закон № 96), направленный, на устранение выявленных пробелов в законодательном регулировании механизма противодействия нарушениям в области охраны объектов культурного наследия.

В настоящее время КоАП РФ содержит 13 составов административных правонарушений (ст.ст. 7.13-7.16, 7.33), объединенных общим объектом - общественными отношениями, возникающими в связи с сохранением, использованием, популяризацией и охраной объектов культурного наследия.

Согласно закрепленным в ст.ст. $7.13-7.16,7.33$ КоАП РФ составам административных правонарушений к противоправным деяниям, за совершение которых предусмотрена административная ответственность, относятся:

нарушение требований сохранения, использования и государственной охраны объектов культурного наследия (памятников истории и культуры) народов Российской Федерации, за исключением выявленных объектов культурного наследия, нарушение режима использования земель в границах территорий объектов культурного наследия, за исключением выявленных объектов культурного наследия, либо несоблюдение ограничений, установленных в границах зон охраны объектов культурного наследия, за исключе-

Собрание законодательства Российской Федерации. 2010. № 13. Ст. 1409. нием выявленных объектов культурного наследия (ч. 1 ст. 7.13);

действия (бездействие), предусмотренные ч. 1 ст. 7.13, совершенные в отношении особо ценных объектов культурного наследия народов Российской Федерации, объектов культурного наследия, включенных в Список всемирного наследия, на территориях указанных объектов, на территориях историко-культурных заповедников (музеев-заповедников) либо в их зонах охраны (ч. 2 ст. 7.13 );

действия (бездействие), предусмотренные ч. 1 ст. 7.13, совершенные в отношении выявленных объектов культурного наследия или на их территориях (ч. 3 ст. 7.13);

неисполнение или ненадлежащее исполнение должностным лицом возложенных на него должностных обязанностей, повлекшие причинение вреда объекту культурного наследия, в том числе выявленному объекту культурного наследия, либо уничтожение объекта культурного наследия, в том числе выявленного объекта культурного наследия, если эти действия не содержат уголовно наказуемого деяния (4. 4 ст. 7.13);

организация или проведение земляных, строительных, мелиоративных, хозяйственных и иных работ без разрешения государственного органа охраны объектов культурного наследия в случаях, если такое разрешение обязательно (ст. 7.14);

уничтожение или повреждение объектов культурного наследия (памятников истории и культуры) народов Российской Федерации, в том числе выявленных объектов культурного наследия (ч. 1 ст. 7.14.1);

действия (бездействие), предусмотренные ч. 1 ст. 7.14.1, совершенные в отношении особо ценных объектов культурного наследия народов Российской Федерации либо объектов культурного наследия, включенных в Список всемирного наследия (ч. 2 ст. 7.14.1);

неисполнение заказчиком и (или) исполнителем работ обязанности по приостановлению земляных, строительных, дорожных или иных работ в случае обнаружения объекта, обладающего признаками объекта культурного наследия в соответствии с законодательством об охране объектов культурного наследия, или работ, проведение которых может ухудшить состояние объекта культурного наследия либо нарушить его целостность и сохранность, после получения письменного предписания государственного органа охраны объектов культурного наследия (ст. 7.14.2);

ведение археологических разведок или раскопок без полученного в установленном порядке разрешения (открытого листа), если эти действия не содержат уголовно наказуемого деяния, либо с нарушением 
условий, предусмотренных разрешением (открытым листом) (ч. 1 ст. 7.15);

действия, предусмотренные ч. 1 ст. 7.15, повлекшие по неосторожности повреждение или уничтожение объекта археологического наследия, выявленного объекта археологического наследия (ч. 2 ст. 7.15);

действия, предусмотренные ч. 1 ст. 7.15, совершенные с использованием специальных технических средств поиска и (или) землеройных машин (ч. 3 ст. 7.15);

незаконное предоставление земельных участков из состава земель историко-культурного назначения, незаконное изменение правового режима земельных участков из состава земель историко-культурного назначения (ст. 7.16);

уклонение от передачи обнаруженных в результате археологических полевых работ культурных ценностей (включая антропогенные, антропологические, палеозоологические, палеоботанические и иные объекты, имеющие историко-культурную ценность) на постоянное хранение в государственную часть Музейного фонда Российской Федерации (ст. 7.33).

В связи с многочисленными поправками, внесенными в КоАП РФ и другие нормативные правовые акты Федеральным законом № 96 и Федеральным законом № 245, рассмотрим охранительные нормы КоАП РФ в свете ряда законодательных новелл.

Статья 7.13 КоАП РФ изложена в редакции Федерального закона № 96 и состоит из четырех частей. Следует отметить, что в отличие от прежней редакции часть первая статьи предусматривает административную ответственность за нарушение требований сохранения, использования и государственной охраны объектов культурного наследия, нарушение режима использования земель в границах территорий объектов культурного наследия, а также несоблюдение ограничений, установленных в границах зон охраны объектов культурного наследия, независимо от категории историко-культурного значения объекта культурного наследия. Ранее ответственность наступала за указанные действия (бездействие) только в отношении объектов культурного наследия федерального значения. Таким образом, по замыслу федерального законодателя, установление административной ответственности за правонарушения, совершенные в отношении объектов культурного наследия регионального и местного (муниципального) значения, а также их территорий и зон охраны, должно было регулироваться законами субъектов РФ. В связи с принятием и вступлением в силу в августе 2013 года Федерального закона № 96 от региональных властей во избежание дублирования федеральных охранительных норм потребуется признать утратившими силу составы, предусматривающие ответственность за нарушение требований сохранения, использования и охраны объектов культурного наследия регионального и местного (муниципального) значения.

Частью второй статьи предусмотрена ответственность за противоправные деяния, совершенные в отношении особо ценных объектов культурного наследия народов РФ, объектов культурного наследия, включенных в Список всемирного наследия, на территориях указанных объектов, на территориях историко-культурных заповедников (музеев-заповедников) либо в их зонах охраны. Суть новации заключается в том, что теперь противоправное деяние будет квалифицироваться по части второй рассматриваемой статьи независимо от того, имеет ли историко-культурный заповедник федеральное, региональное или местное (муниципальное) значение.

Часть третья рассматриваемой статьи не претерпела изменений, она по-прежнему обеспечивает защиту выявленных объектов культурного наследия и их территорий от противоправных деяний.

В отличие от прежней редакции статьи, действующая редакция включает четвертую часть, где противоправное деяние заключается в неисполнении или ненадлежащем исполнении должностным лицом возложенных на него должностных обязанностей, которые повлекли причинение вреда объекту культурного наследия, в том числе выявленному объекту культурного наследия, либо уничтожение объекта культурного наследия, в том числе выявленного объекта культурного наследия, если эти действия не содержат уголовно наказуемого деяния.

Статья 7.14 КоАП РФ подверглась незначительным изменениям. Теперь противоправным деянием признается не только проведение земляных, строительных или иных работ без разрешения государственного органа охраны объектов культурного наследия, но и организация таких работ. ${ }^{4}$

Кодекс Российской Федерации об административных правонарушениях дополнен статьями 7.14.1 и 7.14.2.

Статья 7.14.1 устанавливает административную ответственность юридических лиц за уничтожение или повреждение объектов культурного наследия, в том числе выявленных объектов культурного насле-

4 О неопределенности в вопросе установления норм Федерального закона № 73, защищаемых санкцией статьи 7.14 КоАП РФ, см.: Панфилов А.Н. Проблемы применения мер административной ответственности за отдельные правонарушения в сфере охраны объектов культурного наследия в Российской Федерации // Государство и право. 2012. № 8. С. $28-30$. 
дия (часть первая), а также за уничтожение или повреждение особо ценных объектов культурного наследия либо объектов культурного наследия, включенных в Список всемирного наследия (часть вторая).

B cmambe 7.14.2 противоправное деяние выражено в неисполнении заказчиком и (или) исполнителем работ обязанности по приостановлению земляных, строительных, дорожных или иных работ в случае обнаружения объекта, обладающего признаками объекта культурного наследия, или работ, проведение которых может ухудшить состояние памятника либо нарушить его целостность и сохранность, после получения письменного предписания государственного органа охраны памятников.

В статью 7.15 КоАП РФ Федеральным законом № 245 и Федеральным законом № 96 внесены следующие изменения:

В диспозиции части первой статьи сделана оговорка, согласно которой административная ответственность за ведение археологических разведок или раскопок без полученного в установленном порядке разрешения (открытого листа) наступает, если такие действия не содержат уголовно наказуемого деяния.

Часть вторая статьи 7.15 изложена в новой редакции, где объектом посягательства является как объект археологического наследия, так и выявленный объект археологического наследия. В прежней редакции части второй указанной статьи административная ответственность предусматривалась за противоправные деяния лишь в отношении объекта археологического наследия. Данная новелла представляется сомнительной, поскольку в этом случае под объектом археологического наследия нужно понимать объект, включенный в единый государственный реестр объектов культурного наследия (памятников истории и культуры) народов Российской Федерации. Однако дефиниция "объект археологического наследия» в части второй статьи 3 Федерального закона № 73 указанный признак не содержит. Думается, что понятие «объект археологического наследия» является родовым по отношению к понятию «выявленный объект археологического наследия».

Кроме того, нуждается в уточнении материальный состав административного правонарушения, предусмотренного в ч. 2 ст. 7.15 КоАП РФ. Санкцией части второй данной статьи определяется больший размер административного штрафа, в случае если действия, предусмотренные ее первой частью, повлекли по неосторожности повреждение или уничтожение объекта археологического наследия. Здесь по-прежнему вызывает вопрос субъективная сторона правонарушения, а именно вина правонарушителя в форме неосторожности.
В теории права административное правонарушение признается совершенным по неосторожности, если лицо, его совершившее, предвидело возможность наступления вредных последствий своего действия (бездействия), но без достаточных к тому оснований самонадеянно рассчитывало на предотвращение таких последствий, либо не предвидело возможности наступления таких последствий, хотя должно было и могло их предвидеть. ${ }^{5}$ Однако проведение археологических полевых работ является осознанным действием лица, которое не может не предвидеть наступление вредных последствий для объекта археологического наследия. Предвидя наступление вредных последствий для объекта археологического наследия, лицо, производящее эти работы, не может не желать их наступления. Более того, ведение любых раскопок памятников археологии приводит к повреждению культурного слоя, остатков сооружений и объектов, а полные раскопки фактически являются их уничтожением. В отличие от объектов культурного наследия, представленных зданиями и сооружениями, воссоздать культурный слой древнего памятника невозможно. Это всегда невосполнимая утрата.

Надо полагать, повреждение или уничтожение объекта археологического наследия при проведении археологических полевых работ может быть только умышленным. Соответственно такие действия в отношении граждан и должностных лиц следует квалифицировать по ст. 243 Уголовного кодекса РФ.

Федеральный закон № 245 дополнил статью 7.15 КоАП новым составом (частью 3), где противоправное деяние выражается в действиях, предусмотренных частью 1 этой статьи, совершенных с использованием специальных технических средств поиска и (или) землеройных машин. Также часть 3 статьи дополнена примечанием, раскрывающим понятие «специальные технические средства поиска», под которыми понимаются металлоискатели, радары, магнитные приборы и другие технические средства, позволяющие определить наличие археологических предметов в месте залегания. Таким образом, использование специальных технических средств поиска при проведении несанкционированных археологических полевых работ выступает в качестве квалифицирующего признака состава правонарушения, служащего обстоятельством, отягчающим административную ответственность и влекущим более строгое наказание.

Санкции ст. 7.15 предусматривают дополнительное административное наказание в виде конфиска-

5 Административное право: учебник для вузов / Д.Н. Бахрах, Б.В. Россинский, Ю.Н. Старилов. - 3-е изд., пересмотр. и доп. М.: Норма, 2008. С. 559. 
ции предметов, добытых в результате раскопок, а также инструментов и оборудования, использованных для разведок или раскопок (в ч. 3 дополнительно - специальных технических средств поиска и (или) землеройных машин). Очевидно, что здесь имеет место коллизия между положениями ст. 7.15 и ст. 3.7 КоАП РФ. ${ }^{6}$ Согласно ч. 1 ст. 3.7 КоАП РФ конфискацией орудия совершения или предмета административного правонарушения является принудительное безвозмездное обращение в федеральную собственность или в собственность субъекта Российской Федерации не изъятых из оборота вещей. Частью 3 ст. 3.7 КоАП РФ установлено, что не является конфискацией изъятие из незаконного владения лица, совершившего административное правонарушение, орудия совершения или предмета административного правонарушения, изъятых из оборота либо находившихся в противоправном владении лица, совершившего административное правонарушение, по иным причинам и на этом основании подлежащих обращению в собственность государства или уничтожению. Стало быть, нахождение объектов археологического наследия, а также всех движимых предметов, имеющих к ним отношение, в государственной собственности (п. 3 ст. 49 Федерального закона № 73) исключает их конфискацию. В этой связи представляется верной точка зрения об исключении из санкций ст. 7.15 КоАП РФ упоминания о конфискации предметов, добытых в результате раскопок, оставив лишь конфискацию инструментов и оборудования. ${ }^{7}$

Статья 7.16 КоАП РФ включает в себя один состав административного правонарушения. Объективная сторона правонарушения выражается в незаконном предоставлении земельных участков из состава земель историко-культурного назначения, незаконном изменении правового режима земельных участков из состава земель историко-культурного назначения.

Данная статья призвана обеспечить мерами административной ответственности защиту объектов культурного наследия (памятников истории и культуры) народов Российской Федерации и других объектов, указанных в ст. 99 Земельного кодекса Российской Федерации (далее - Земельный кодекс). По мнению И.В. Богомякова, основным целевым назначением земель историко-культурного наследия является то, что они служат пространственным базисом для обеспечения

6 Вахитов А.К. Административно-правовая охрана объектов культурного наследия: автореф. дис. ... канд.юрид.наук: 12.00.14. M., 2007. C. 23.

7 Вахитов А.К. Там же. физической сохранности расположенных на указанных землях объектов культурного наследия. ${ }^{8}$

Следует отметить, что Земельный кодекс содержит более широкий перечень объектов, земли которых относятся к землям историко-культурного назначения, чем Федеральный закон № 73. Так, военные и гражданские захоронения, перечисленные в ст. 99 Земельного кодекса, могут не иметь статуса объекта культурного наследия или выявленного объекта культурного наследия. Вдобавок Земельный кодекс отдельно выделяет земли достопримечательных мест.

Напротив, Федеральный закон № 73:

относит к землям историко-культурного назначения лишь земельные участки в границах территорий объектов культурного наследия, включенных в единый государственный реестр объектов культурного наследия (далее - реестр), а также в границах территорий выявленных объектов культурного наследия (ст. 5);

определяет достопримечательное место как вид объекта культурного наследия, наряду с памятником и ансамблем (ст. 3);

устанавливает различный режим использования в отношении территории памятника, ансамбля (п. 2 ст. 35) и территории достопримечательного места (п. 3 ст. 35). В отличие от территории памятника или ансамбля, где Федеральным законом № 73 установлен запрет на проектирование и проведение землеустроительных, земляных, строительных, мелиоративных, хозяйственных и иных работ, за исключением работ по их сохранению, сохранению их территорий, а также хозяйственной деятельности, не нарушающей их целостности и не создающей угрозы их повреждения, разрушения или уничтожения, характер использования территории достопримечательного места, ограничения на использование данной территории и требования к хозяйственной деятельности, проектированию и строительству на территории достопримечательного места определяются соответствующим органом охраны объектов культурного наследия.

Правовой режим земель историко-культурного назначения регулируется земельным законодательством Российской Федерации и Федеральным законом № 73. В соответствии со ст. 99 Земельного кодекса земли историко-культурного назначения используются строго в соответствии с их целевым назначением, изменение целевого назначения данных земель и не соответствующая их целевому назначению деятельность не допускаются.

8 Богомяков И.В. Содержание понятия «земли историко-культурного назначения» в Земельном кодексе Российской Федерации // Экологическое право. 2011. № 1. С. 9. 
Согласно ст. 94 Земельного кодекса земли историко-культурного назначения относятся к землям особо охраняемых территорий. Порядок отнесения земель к землям особо охраняемых территорий федерального, регионального и местного значения, порядок использования и охраны таких земель устанавливаются соответственно Правительством РФ, органами государственной власти субъектов РФ и органами местного самоуправления в соответствии с федеральными законами, законами субъектов РФ и муниципальными правовыми актами.

Сложность квалификации действий должностного лица, осуществляющего предоставление земельных участков, по ст. 7.16 КоАП РФ заключается в том, что субъекту применения административной ответственности необходимо доказать принадлежность предоставленного земельного участка, либо земельного участка, в отношении которого изменен правовой режим, к землям историко-культурного назначения.

В соответствии со ст. 14 Федерального закона от 21 декабря 2004 г. № 172-Ф3 «О переводе земель или земельных участков из одной категории в другую» (далее - Федеральный закон № 172) отнесение земель или земельных участков в составе таких земель к одной из установленных Земельным кодексом категорий земель является обязательным. Однако земли историко-культурного назначения не возникают сами по себе. Их появлению предшествует деятельность уполномоченных органов исполнительных власти субъектов РФ по выявлению и учету объектов, представляющих собой историко-культурную ценность, установлению границ их территорий (ст.ст. 18, 33 Федерального закона № 73).

Акт органа государственной власти об утверждении границ территории объекта культурного наследия, включенного в реестр, или выявленного объекта культурного наследия является основанием для перевода земель другой категории или земельных участков в составе таких земель в земли особо охраняемых территорий и объектов (за исключением земель населенных пунктов). Причем такой перевод будет считаться состоявшимся с даты осуществления государственного кадастрового учета земельных участков в связи с изменением их категории (ч. 3 ст. 5 Федерального закона № 172).

В случае принятия решений об отказе включить выявленный объект культурного наследия в реестр, об исключении объекта культурного наследия из реестра, должна быть осуществлена процедура перевода земель особо охраняемых территорий и объектов или земельных участков в составе таких земель в другую категорию в соответствии с ч. 1 ст. 10 Федерального закона № 172.
Статья 7.33 КоАП РФ введена Федеральным законом от 26 июля 2006 г. № 133-Ф3 «О внесении изменений в Кодекс Российской Федерации об административных правонарушениях" и содержит один состав правонарушения. Объективная сторона правонарушения, предусмотренного данной статьей, выражается в уклонении от передачи обнаруженных в результате археологических полевых работ культурных ценностей (включая антропогенные, антропологические, палеозоологические, палеоботанические и иные объекты, имеющие историко-культурную ценность) на постоянное хранение в государственную часть Музейного фонда РФ. ${ }^{9}$

Статьей 7.33 КоАП РФ определены административные санкции в отношении граждан, должностных лиц и юридических лиц за нарушение норм Федерального закона № 73, обеспечивающих сохранность объектов археологического наследия и доступ к ним в публичных интересах:

- объекты археологического наследия, включая все движимые предметы, имеющие к ним отношение, находятся в государственной собственности (п. 3 ст. 49);

- объекты археологического наследия отчуждению из государственной собственности не подлежат (п. 1 ст. 50);

- исполнитель археологических полевых работ физическое лицо, проводившее археологические полевые работы, и юридическое лицо, в трудовых отношениях с которым состоит такое физическое лицо, в течение трех лет со дня окончания срока действия разрешения (открытого листа) обязаны передать в порядке, установленном федеральным органом охраны объектов культурного наследия, все изъятые археологические предметы (включая антропогенные, антропологические, палеозоологические, палеоботанические и иные объекты, имеющие историко-культурную ценность) в государственную часть Музейного фонда РФ (п. 13 ст. 45.1).

9 В июле 2015 года вступает в силу пункт 3 статьи 5 Федерального закона № 245, в соответствии с которым изменятся наименование и диспозиция статьи 7.33 КоАП РФ. Противоправное деяние будет выражаться в уклонении исполнителя земляных, строительных, мелиоративных, хозяйственных или иных работ либо археологических полевых работ, осуществляемых на основании разрешения (открытого листа), от обязательной передачи государству в соответствии с законодательством Российской Федерации культурных ценностей, обнаруженных в результате проведения таких работ, если это действие не содержит уголовно наказуемого деяния. 
Согласно ст. 13 Федерального закона от 26 мая 1996 г. № 54-Ф3 «О Музейном фонде Российской Федерации и музеях в Российской Федерации» в состав государственной части Музейного фонда РФ входят музейные предметы и музейные коллекции, находящиеся в федеральной собственности и в собственности субъектов РФ, независимо от того, в чьем владении они находятся.

Порядок включения музейных предметов и музейных коллекций в состав государственной части Музейного фонда РФ, а также порядок их учета и хранения регулируются Положением о Музейном фонде Российской Федерации, утвержденным постановлением Правительства РФ от 12 февраля 1998 г. № 179, и Инструкцией по учету и хранению музейных ценностей, находящихся в государственных музеях СССР, утвержденной приказом Министерства культуры СССР от 17 июля 1985 г. № 290 (далее - Инструкция). ${ }^{10}$ Между тем Инструкция не регулирует должным образом порядок и условия передачи на постоянное хранение в государственную часть Музейного фонда РФ культурных ценностей, полученных в результате археологических полевых работ (см., например, п. 100). Материалы, извлеченные из культурного слоя определенного памятника археологии, в сущности, представляют собой совокупность культурных ценностей (антропогенных, антропологических, палеозоологических, палеоботанических и иных) и должны рассматриваться как единая коллекция. Это объекты не только музейного показа, но и научного интереса. Археологические материалы должны включаться в государственную часть Музейного фонда РФ независимо от того, относятся они к уникальным или однотипным. Думается, что процедура их передачи могла бы быть урегулирована специальным нормативным правовым актом.

Обращаясь к законодательным новеллам Федерального закона № 245, нельзя не упомянуть еще об одном составе административного правонарушения. Дело в том, что в июле 2014 года вступает в силу пункт 2 статьи 5 указанного закона, в соответствии с которым КоАП РФ дополняется статьей 7.15.1, предусматривающей административную ответственность за незаконный оборот археологических предметов.

За совершение административных правонарушений, предусмотренных ст.ст. 7.13 - 7.16, 7.33 КоАП РФ, преимущественно установлено наказание в виде административного штрафа. Лишь санкции статьи 7.15 помимо административного штрафа, устанавливае-

10 Приказ Минкультуры СССР от 17.07.1985 № 290 был отменен приказом Минкультуры России от 08.12.2009 № 842 , который впоследствии отменен приказом Минкультуры России от 11.03.2010 № 116. мого в качестве основного административного наказания, дополнительно предусматривают такой вид наказания, как: «конфискация предметов, добытых в результате раскопок, а также инструментов и оборудования, использованных для разведок или раскопок». Санкция части 3 статьи 7.15 кроме предметов, добытых в результате раскопок, а также инструментов и оборудования, использованных для разведок или раскопок, предусматривает конфискацию специальных технических средств поиска и (или) землеройных машин.

Субъекты большинства правонарушений - граждане, должностные лица и юридические лица (ч. 1 - ч. 3 ст. 7.13, ст.ст. 7.14, 7.14.2, 7.15, 7.33). Однако субъектами административных правонарушений, предусмотренных ст. 7.14.1 КоАП РФ, являются исключительно юридические лица, а ч. 4 ст. 7.13, ст. 7.16 - должностные лица.

Весьма важен вопрос о размерах административных штрафов за нарушение требований в сфере охраны памятников, которые в связи с вступлением в силу Федерального закона № 96 значительно увеличены. Путем редактирования абзаца первого части 1 статьи 3.5 КоАП РФ установлены максимальные размеры административных штрафов за правонарушения в области сохранения, использования и охраны объектов культурного наследия: для граждан - триста тысяч рублей, для должностных лиц - шестьсот тысяч рублей, для юридических лиц - шестьдесят миллионов рублей. Например, санкция в ч. 1 ст. 7.13 КоАП РФ в новой редакции предусматривает следующие размеры административных штрафов: для граждан - от пятнадцати тысяч до двухсот тысяч рублей, для должностных лиц - от двадцати тысяч до четырехсот тысяч рублей, для юридических лиц - от двухсот тысяч до пяти миллионов рублей. Уничтожение или повреждение объекта культурного наследия любой категории историко-культурного значения, а также выявленного объекта культурного наследия повлечет наложение административного штрафа на юридических лиц в размере от пятисот тысяч до двадцати миллионов рублей (ч. 1 ст. 7.14.1). За аналогичные противоправные деяния, совершенные юридическим лицом в отношении особо ценных объектов культурного наследия либо объектов культурного наследия, включенных в Список всемирного наследия, предусмотрен административный штраф в размере от одного миллиона до шестидесяти миллионов рублей (ч. 2 ст. 7.14.1).

Обращает на себя внимание не только чрезмерно высокие размеры административных штрафов, но и значительный разрыв между их нижними и верхними пределами. Так, например, санкция в ч. 2 ст. 7.13 КоАП РФ предусматривает в отношении юридических лиц административный штраф в размере om одного мил- 
лиона до двадцати миллионов рублей. Несомненно, такая разница в нижнем и верхнем пределах штрафа недопустима, поскольку создает возможность субъективного усмотрения правоприменителя.

Ученые-административисты отмечают общую тенденцию ужесточения административных наказаний физических и юридических лиц за наиболее вредоносные административные правонарушения. ${ }^{11}$ Вместе с тем полагаем справедливым утверждение О.С. Рогачевой, что «тенденция возрастания размера административных штрафов за административные правонарушения приводит к тому, что штраф уже нельзя считать критерием отграничения административных правонарушений и преступлений, имея в виду большую степень общественной опасности последних». ${ }^{12}$

С недавнего времени в КоАП РФ изменилась подведомственность дел об административных правонарушениях в области сохранения, использования и охраны памятников истории и культуры. До вступления в силу Федерального закона № 96 к кругу субъектов применения административной ответственности за правонарушения, предусмотренные ст.ст. 7.13 - 7.16, 7.33 КоАП РФ, относились органы, осуществляющие государственный контроль в области сохранения, использования, популяризации объектов культурного наследия и их государственную охрану, и мировые судьи. Последние уполномочены были рассматривать дела об административных правонарушениях, предусмотренных статьей 7.15. Протоколы об административных правонарушениях составлялись должностными лицами органов, осуществляющих государственный контроль в области сохранения, использования, популяризации и государ- ственной охраны объектов культурного наследия (ст.ст. 7.13, 7.14, 7.15, 7.16, 7.33), должностными лицами органов внутренних дел (полиции) (ст.ст. 7.13, 7.14, 7.15).

Новеллы Федерального закона № 96 особую роль в рассмотрении дел об административных правонарушениях в сфере охраны памятников отвели судьям районных судов. Им подведомственны дела об административных правонарушениях, предусмотренных статьями 7.13 - 7.16 КоАП РФ. Напротив, административная юрисдикция органов, осуществляющих государственный контроль в области государственной охраны памятников, сузилась. В их компетенции осталось лишь рассмотрение дел об административных правонарушениях, предусмотренных ст. 7.33 КоАП РФ.

К заслуживающим внимания изменениям, внесенным в КоАП РФ Федеральным законом № 96, нужно отнести и другие законодательные новации. Так, в отдельные составы выделены правонарушения, выраженные:

в невыполнении в установленный срок законного предписания органа, уполномоченного осуществлять государственный контроль в области сохранения, использования, популяризации и государственной охраны объектов культурного наследия (ч. 18 ст. 19.5);

в повторном совершении аналогичного административного правонарушения (ч. 19 ст. 19.5).

Также трудно переоценить значение поправки в КоАП РФ, согласно которой срок давности привлечения к административной ответственности за нарушение законодательства об охране объектов культурного наследия (памятников истории и культуры) народов Российской Федерации увеличен с двух месяцев до одного года (ч. 1 ст. 4.5).

\section{Библиография}

1. Административное право: учебник для вузов / Д.Н. Бахрах, Б.В. Россинский, Ю.Н. Старилов. - 3-е изд., пересмотр. и доп. М.: Норма, 2008.

2. Богомяков И.В. Содержание понятия «земли историко-культурного назначения» в Земельном кодексе Российской Федерации // Экологическое право. 2011. № 1.

3. Вахитов А.К. Административно-правовая охрана объектов культурного наследия: автореф. дис. ... канд. юрид.наук: 12.00.14. М., 2007.

11 Салищева Н.Г. О некоторых тенденциях развития законодательства об административной ответственности в России в современный период // Административное право и процесс. 2009. № 5. С. 5 - 12.

12 Рогачева О.С. Эффективность норм административно-деликтного права: монография. Воронеж: Издательство Воронежского государственного университета. 2011. С. 6. 
Административное и муниципальное право 12 (72) • 2013

4. Панфилов А.Н. Проблемы применения мер административной ответственности за отдельные правонарушения в сфере охраны объектов культурного наследия в Российской Федерации // Государство и право. 2012 . № 8.

5. Панфилов А.Н. Охранительные нормы административно-деликтного законодательства субъектов Российской Федерации в сфере охраны объектов культурного наследия // Право и политика. 2013. №

6. Рогачева О.С. Эффективность норм административно-деликтного права: монография. Воронеж: Издательство Воронежского государственного университета. 2011.

7. Салищева Н.Г. О некоторых тенденциях развития законодательства об административной ответственности в России в современный период // Административное право и процесс. 2009. № 5.

8. Сумачев А.В. К вопросу о понятии культурных ценностей и совершенствовании административно-правового режима их охраны // Право и политика. 2012. № 12.

\section{References}

1. Administrativnoe pravo: uchebnik dlya vuzov / D.N. Bakhrakh, B.V. Rossinskii, Yu.N. Starilov. - 3-e izd., peresmotr. i dop. M.: Norma, 2008.

2. Bogomyakov I.V. Soderzhanie ponyatiya «zemli istoriko-kul'turnogo naznacheniya» v Zemel'nom kodekse Rossiiskoi Federatsii // Ekologicheskoe pravo. 2011. № 1.

3. Vakhitov A.K. Administrativno-pravovaya okhrana ob"ektov kul'turnogo naslediya: avtoref. dis. ... kand.yurid.nauk: 12.00.14. M., 2007.

4. Panfilov A.N. Problemy primeneniya mer administrativnoi otvetstvennosti za otdel'nye pravonarusheniya $v$ sfere okhrany ob"ektov kul'turnogo naslediya v Rossiiskoi Federatsii // Gosudarstvo i pravo. 2012. № 8.

5. Panfilov A.N. Okhranitel'nye normy administrativno-deliktnogo zakonodatel'stva sub"ektov Rossiiskoi Federatsii v sfere okhrany ob"ektov kul'turnogo naslediya // Pravo i politika. 2013. №

6. Rogacheva O.S. Effektivnost' norm administrativno-deliktnogo prava: monografiya. Voronezh: Izdatel'stvo Voronezhskogo gosudarstvennogo universiteta. 2011.

7. Salishcheva N.G. O nekotorykh tendentsiyakh razvitiya zakonodatel'stva ob administrativnoi otvetstvennosti v Rossii v sovremennyi period // Administrativnoe pravo i protsess. 2009. № 5.

8. Sumachev A.V. K voprosu o ponyatii kul'turnykh tsennostei i sovershenstvovanii administrativno-pravovogo rezhima ikh okhrany // Pravo i politika. 2012. № 12. 